Article

\title{
On-line Crowdsourcing: Motives of Customers to Participate in Online Collaborative Innovation Processes
}

\author{
Carlota Lorenzo-Romero ${ }^{1}$ and Efthymios Constantinides ${ }^{2, *}$ \\ 1 Business Administration Department, University of Castilla-La Mancha, 02071 Albacete, Spain; \\ carlota.lorenzo@uclm.es \\ 2 Faculty BMS /EISM, University of Twente, 7500 Enschede, The Netherlands \\ * Correspondence: e.constantinides@utwente.nl; Tel.: +31-534893799
}

Received: 29 May 2019; Accepted: 22 June 2019; Published: 25 June 2019

\begin{abstract}
The large-scale adoption of the Internet and social media make transactions and interactions between businesses and customers easy, inexpensive, and highly efficient. Online crowdsourcing and co-creation with customers are developments increasingly seen as attractive alternatives to traditional forms of innovation management. Online customers are willing to spend time and effort on collaborative innovation trajectories and so have a say in the development of new products and services. Identifying and recruiting capable and innovation-minded co-creation partners online is one of the main challenges of such collaborative innovation-focused processes; understanding the attitudes and motives of innovation-minded customers are the first steps in enticing and recruit these as innovation partners. In this study, we identify and classify customer motives for participating in online co-creation processes in two European countries: Spain and The Netherlands. More than a quarter of online customers are active co-creators and two co-creator profiles were identified in both countries, based the levels of motivation predisposition; Spanish online customers are more involved and enthusiastic co-creators than Dutch customers. The study confirms that financial motives are not the main reason for co-creation; highly motivated customers are motivated by product-related benefits, while hedonic benefits are the most important triggers for less motivated co-creators.
\end{abstract}

Keywords: digital marketing; co-creation; innovation; crowdsourcing; online consumer segmentation; comparative study

\section{Introduction}

Customer participation in new product and service development projects is an established practice among marketers and is an important and promising approach in the innovation domain [1-4]; the crowd-based innovation is an evolving innovation research field [5]. The term "co-creation" is explained by [6] as 'the creation of a partnership between companies and/or institutes and/or customers on sharing knowledge, costs and benefits in order to create unique value for the customer' and is viewed as a means to effectively tap into the collective intelligence of consumers [7]. Terms synonymous to co-creation include "crowdsourcing", "collaborative innovation", "co-innovation" and "Virtual Customer Integration" (VCI) [8]. Gemser and Perks [5] identifies 21 terms that are used as key words of this term. All these terms describe interactions between businesses and customers where the final customer is value co-creation $[2,9]$.

The development of the Internet and, in particular, the emergence of the interactive Web-widely known as Web 2.0 on social media-have added a new dimension to co-creation interactions and present businesses with the opportunity to recruit co-creating customers much more easily, cheaply, 
and on a global scale [10]. Online crowdsourcing communities can operate as continuous co-creation platforms, but interaction with innovative customers can also be case-based or even take the form of quizzes, competitions, hackathons, and challenges. In general, there are many different forms of platforms where co-creation activity can take place [11].

Successful examples of online co-creation can be found in almost any business category and the implications of co-creation are, by now, well understood [12]. However, despite positive experiences, the broader adoption of online co-creation as a business practice has been relatively slow [13]. The McKinsey Global Institute [14] study indicates that "just 3\% of companies are fully networked and use social media to interact with customers, partners and employees".

Open Innovation and co-creation in traditional market settings are topics frequently discussed in the literature; yet issues like dealing with large volumes of customer generated ideas pose important challenges [12] and scientific thinking and business paradigm are "still in flux" [5]. Issues under investigation on this domain include the design and operation of co-creation platforms $[15,16]$ and how to make such platforms engaging [17]. One of the areas where limited research attention has been paid is the identification of ways to promote the open innovation to the public and importantly how to attract the most promising and capable customers as partners in online co-creation projects. Attention on this point includes some pioneering cases of co-creation like the Free Open Source Software (F/OSS) with applications such as Apache, Linux, and Mozilla [18-20]. In the same line, Rohrbeck et al. [21] described how the Deutsche Telekom created an online open innovation ecosystem. In the last years became evident that the value of co-creation is an issue of interest not only for co-creating customers and producers but also for other parties and marketing domains or actors [22] while co-production and value-in-use are the "core conceptual dimensions" of value co-creation [23].

Finding and attracting the innovation-minded potential co-creation partners is one of the main challenges of co-creation trajectories but research about expectations and motives of innovation-minded customers is limited. According to Füller [24], "Little is known about ... how are consumers" expectations affected by their motivations and how does one's personality affect those motives?" Bharti et al. [25] identify drivers of customer participation in co-creation processes in India, arguing that customers' and marketers' views on this issue are quite closely related.

The objective of this study is to analyze and classify the profiles of innovative co-creating consumers in two EU countries, the Netherlands (NL) and Spain (SP), and compare their motivations of being active in web co-creation tasks. The countries in question have different cultural backgrounds and characteristics $[26,27]$ and have shown different rates of adoption of Internet technology. The Netherlands is one of the top countries in Europe and worldwide in terms of Internet and social media penetration, while Spain is a country with lower adoption and lower usage rates of the Internet [28]. Previous studies comparing the online behavior of the two countries found no substantial differences in the online consumer behavior of the residents of these two culturally diverse countries. The central question this study will address is whether different cultural characteristics have an effect on the attitudes of Dutch and Spanish people as potential innovators of online co-creation processes.

\section{Materials and Methods}

Some barriers that prevent organizations from differentiating themselves versus the others similar to them, in today's competitive market settings are, mainly, deregulation, outsourcing, globalization, and the convergence of industries and technologies [3]. In addition, the posture of the customer has been transformed: From isolated to connected, from unaware to informed, from passive to active [2]. Nowadays, a consumer is online, involved, and technology smart. Increasing customer empowerment and difficulty in differentiating firms offer are forcing to businesses to seek active collaboration with their product users in a manner that makes it possible to identify their dormant needs [9] and desires. The benefits can be substantial, and co-creation is a potential new source of competitive advantage: Lower research and development costs, shorter time to market, and greater chances of product success 
are also important advantages of the increasing customer empowerment through involvement in innovation processes [29].

In this background, co-creation with customers is an evolving field of research and practice. The term co-creation is used interchangeably with terms like co-innovation, crowdsourcing, and collaborative innovation while several keywords lead to publications related to this topic [5]. All these terms lead to research on value creation through innovation with customer participation. The active involvement of the customer in innovation trajectories is an alternative path to traditional innovation approaches. The customer involvement can occur in various stages of the new product development (NPD) process leading to faster, cheaper, and more successful new products [12].

\subsection{The Social Media as Interaction Platforms}

A variety of social media platforms have been adopted by Internet users worldwide as social networking and communication platforms. Online interactions underpin the virtual customer integration concept [30,31], involving online customers in every stage of the NPD while also tapping into their knowledge, creativity, and judgment [8]. With increasing direct customer involvement, manufacturers can benefit from interactions taking place in customer forums, social networks, and online communities [10,32] where customers share information, ideas, and suggestions [4].

\subsection{Motivators: The Uses and Gratifications Theory}

Customer expertise, knowledge, and loyalty are important qualities for co-creating customers if firms want to maximize their co-creation benefits [12]. Understanding the customer motives for participating in virtual co-creation projects is a vital step in identifying, selecting, and recruiting the right type of customers. Hoyer et al. [33] identify three levels of co-creation antecedents: Motivators of consumer, deterrents of companies, and stimulators of companies. Füller et al. [8] indicate that financial or other types of compensation are relatively weak triggers for participation in co-creation activities; the desire for product improvements, interest in innovation, pursuit of knowledge and willingness to help companies are important sources of motivation. Consumers participating in co-creation processes often want to test their competence and their self-marketing, and they use core competences to obtain an advantage in addressing a challenge; in addition, consumers like to observe the new concepts proposed by other community members [13].

The factors motivating consumers to participate in activities of online co-creation are cognition, personal and social integration, hedonism [34], and financiering activities [33]. Often, customers expect to be recognized for their co-creation contributions [35], thus improving their reputation and career prospects in addition to helping to recruit new clients [33,36]. Consumer-level variables that are likely to act as motivators in this study are classified into four factors: Social, technical, and psychological categories.

Applied to mass media communications [37] and new electronic communications tools [38], the Uses and Gratifications theory (UG) provides a framework of motivators based on a functionalistic perspective on mass media communications as a means to explain user motivations and associated behavior. Eighmey and McCord [39] drew on the UG perspective to examine the audience experience associated with websites. UG helps illuminate the Internet as a broad range of communication opportunities by "laying out a taxonomy of just what goes on in cyberspace" [40]. Ruggiero [41] asserts that the emergence of computer-mediated communication revived the significance of UG. Within this context, researchers have analyzed UG theory with respect to the use of mobile phone [42]. The UG approach may well play a major role in answering initial web-use questions of curiosity, profit seeking, and sociability [43]. Zolkepli and Kamarulzaman [44] tested the relationship between the UG and social media adoption while considering the mediating effect of innovations in social media; their findings suggest that social media adoption is significantly driven by three types of needs, i.e., "personal needs, social needs and the need for tension release". These needs were reinforced by the innovative characteristics of social media and increase the likelihood of adoption. 
Drawing on previous studies on motivational factors that applied the UG theory to e-consumers $[38,43]$ and co-creators [34,35], we analyzed the profiles of co-creators in two different countries. The UG framework limits the range of motivators to the previously mentioned four variables, reflecting the benefits-positive inputs-that customers can obtain caused by their online interactions on the internet [38,45]. This approach has been used to determine the motives for interest in and adoption of new technologies [37]; however, it has thus far not been used to determine the motivation for co-creation.

\subsection{Research Questions}

Participation in tasks related to online co-creation allows users to gain deeper insights about a product; thus, the product experience is enhanced by the increase of knowledge on goods and the use of technologies. The process of enhanced learning offers cognitive benefits to the customer $[33,34,43,46]$. It is therefore highly likely that users are motivated to be active in tasks related to the processes of co-creation once it is understood that participation offers the possibility of broadening their knowledge of the product as well as its functions, components, and applications. This leads to the first research question:

RQ1: Are the benefits derived from learning about a product a significant source of motivation to engage in online co-creation on social media platforms?

Involvement in the co-creation process of a business enables the customer to interact collaboratively with other customers and company staff [12]. Customers might identify themselves with the community and feel a connection with other members, motivating such customers to participate in co-creation activities $[33,34,43,46,47]$. The second research question can therefore be formulated as follows:

RQ2: Are the benefits of social integration significant as motivation to engage in online co-creation on social media platforms?

Having made a good contribution to developing the goods of firms, the customer has the opportunity to improve his reputation with other users and within the company itself in addition to increasing his expertise regarding the (new) product or service $[33,34,48]$. This could increase the motivation to be active in co-creation processes. For that, we propose the third research question:

RQ3: Are the personal integrative benefits significant as motivation to engage in online co-creation on social media platforms?

As explained previously, co-creation is a process in which users share ideas for new goods and offer their comments for improving them. Involvement in a delightful and joyful activity could motivate the user to be active in co-creation processes $[33,34,46]$. Accordingly, we propose to the following research question:

RQ4: Are hedonic benefits significant as motivation to engage in online co-creation on social media platforms?

Consumers in the Netherlands and Spain are avid users of the social Web, although there are cultural differences [49] and differences in the overall penetration of the Internet in both the analyzed countries. According to Hofstede Insights (2019), the main cultural differences between these two countries are the degree of masculinity (14 points NL versus 42 points SP), individualism ( 80 points NL versus 51 points SP), and uncertainty avoidance ( 53 points NL versus 86 points SP). The rest of insights measured by Hofstede, present a distance of 20 points approximately between both countries, being the power distance higher in SP (38 points NL versus 57 points SP), and long term orientation and indulgence insights in NL ( 67 points NL versus 48 points SP; 68 points NL versus 44 points SP, respectively).

According to Eurostat [28], $98 \%$ of the Dutch and $83 \%$ of the Spanish households have access to the Internet in 2017. In terms of social media adoption, the differences between the two countries are much smaller. In January 2018, 64\% of Dutch Internet users and 58\% of Spanish Internet users 
were monthly active social media users [50]. Additionally, according to data from Statista [51], in 2017, Spanish people spend much more time on daily social media use (98 minutes daily) than Dutch users (80 minutes daily)

Both previous motives-overall penetration of the Internet and the cultural differences between the two countries [52] — could suggest that motivation for online co-creation is dissimilar between them. Possible differences between both countries will be analyzed, and the different behavioral patterns within each country will also be identified (i.e., heterogeneity or homogeneity among the users in each country). In sum, based on the culture and technology habits of both countries, we propose the following research question:

RQ5: Are the co-creators on social media platforms in both countries homogeneous?

\subsection{Methodology}

\subsubsection{Sample of Survey}

To analyze the establishment of concept about online co-creation processes and to identify its differences and similiters, a survey was conducted. The questionnaire was pre-tested with a sample of 5 participants in each country to be sure that individuals understood and interpreted the questions as intended [53]. The final data were collected within a two-week period in March 2018 (the Netherlands) and July 2018 (Spain). The questionnaire explicitly asked the participants about participating in co-creation in social media environments. A list of social media applications (social networks, online communities etc.) commonly used as interaction platforms in online co-creation processes was presented in order to identify the most common platforms used for this purpose by marketers [10].

In the Netherlands, a total of 239 respondents participated, $43 \%$ male and $57 \%$ female, most of them between the ages of 20 and $25(>20$ years $=8.3 \%$; $<25$ years $=19.2 \%)$. The sample included 226 Europeans and 13 non-Europeans, the majority being young student people (86.62\%) and the rest being young professionals (13.38\%). 68 respondents (i.e., $28.4 \%$ ) confirmed full participation in all social media co-creation activities that were presented. In Spain, a total of 334 respondents participated in the survey, $47 \%$ male and $53 \%$ female; most of them were between the ages of 18 and $24(27.2 \%)$ and 40 and 54 years old (22.9\%). 136 respondents (i.e., $40.7 \%$ ) indicated full participation in all co-creation activities that were proposed.

The data from participants with earlier experience in online co-creation projects in both countries were analyzed, and a factorial and latent segmentation analysis was performed.

In both cases, convenience sampling was applied as the sampling method. The questionnaire was distributed through the researchers' social networks, e.g., Facebook, Twitter, and LinkedIn, and also by email. The questionnaire was made available to respondents on the online survey platform SurveyMonkey ${ }^{\circledR}$. Participants were familiar with the Internet environment and should ideally have been in different age categories. The sample is a convenience sample, and in this sense, the findings cannot be generalized to the total population in any of the countries in question. They are, however, representative of the population sharing the sample characteristics in the two countries (Statistical National Institute in Spain (http://www.ine.es/en/welcome.shtml); Centraal Bureau Voor de Statistiek in the Netherlands (https://www.cbs.nl/en-gb)). From a statistical perspective, as explained in section 5.1, both samples showed a consistent and reliable structure due to the acceptance of the statistical indicators (Cronbach's Alfa $>0.7$; factor loading $>0.5$; [54,55]). Moreover, to analyze the validity of the results, the sample (per each country) was separated into two halves, and a factorial analysis was randomly performed for each sample. As the analysis of the loadings does not differ substantially (for each country separately), we can conclude that the results are robust and stable [56].

The questionnaire was divided into the following parts: (1) demographics questions meant to identify general sample characteristics; (2) questions considering the reasons for making use of the Internet and various social media platforms in general; (3) questions concerning online co-creation 
activities, which are an attempt to identify the reasons that non-co-creators do not participate in online innovation processes and co-creators do participate in them.

As well as being a means to compare the possible homogeneity or heterogeneity of online co-creators in both countries (RQ5), the four types of UG Theory antecedents-learning benefits (RQ1), social integrative benefits (RQ2), personal integrative benefits (RQ3), and hedonic benefits (RQ4) - were expected to account as the significant motivators of online co-creators to define their profile.

\subsubsection{Measurement and Methods}

The first empirical goal was to observe any similarities between the factors in previous studies and those in our data. Therefore, the first step consisted in applying exploratory factor analysis (EFA) with SPSS $^{\circledR}$ statistical software. Principal components analysis (PCA) was performed on both databases (the Netherlands and Spain). To operationalize the four constructs of UG Theory [34,43], a 5-point Likert scale was used, ranging from 'strongly disagree' to 'strongly agree'. Each construct was measured three or four items based on previous published works.

The items per constructs were measured as follow:

Learning benefits (RQ1) were measured with three items (i.e., improvement of knowledge of goods, improvement of technology of products, make better decisions for products) $[36,57,58]$.

Social integrative benefits (RQ2) are analysed with four items (i.e., expansion of social network, status enhancement, strengthening community affiliation, enhancing personal career) [57-59].

Personal integrative benefits (RQ3) were analysed with three items (i.e., satisfaction caused by the influence of product design, satisfaction caused by use of products, satisfaction caused by offer of improvements of products and services) proposed by Hertel et al. [58] and Kollock [59]. Four financial items (i.e., the possibility of earning money from co-creation, contributing by making products cheaper, indirectly enhancing the financial position of others by increasing product value, and non-financial rewards, e.g., free products and beta products) measured the construct.

Hedonic benefits (RQ4) were composed by four items (i.e., enjoyment and relaxation, fun and pleasure, entertainment and stimulation, pleasure derived from problem-solving, and idea generation), according to $[57,58]$.

Based on rotated factor scores generated during the EFA analysis, the weighted average of factor items was used as a variable to develop a latent cluster analysis [60,61]. Specifically, a latent segmentation analysis was developed to determine different co-creator profiles in both countries. For that, we incorporated different motives for participating in co-creation activities offered by online companies, as well as, their personal characteristics. Latent segmentation allows to distribute different elements of sample according to their probability of belonging to the segments. It makes break with the restrictions of deterministic assignment which are inherent in non-hierarchic segmentation studies [62]. So, data is generated based on a mixture of distribution probabilities assigned to different clusters-that is, different groups or similar segments that are mixed in unknown proportions [63]. The advantage of carrying out statistical analysis with models based on latent class is that they allow the incorporation of variables with heterogeneous measurement scales (nominal, continual, and ordinal) [64]. The individuals are positioned grouped based on patterns which follow the principles of maximum internal coherence and external differentiation. Latent Gold 4.5 software (Statistical Innovations, Belmont, MA, US) was used to analyze the data in order to study the relationship between each co-creation task and the corresponding cluster using the Wald statistic to take into account the possible significant differences of each co-creation task and its place in each obtained segment. 


\section{Results}

3.1. Factorial Analysis for Dutch and Spanish Samples: Motives for Participation in Online Co-Creation Activities

In terms of the first result of Exploratory Factorial Analysis (EFA), we noted that for both samples, the Kaiser-Meyer-Olkin (KMO) was meritorious, i.e., higher than 0.8 [65], and Bartlett's test was highly significant (0.0000); thus the null hypothesis (i.e., the correlation matrix is an identity matrix) was rejected. This demonstrates the validity of the factorial analysis model for both samples [66,67].

Moreover, to determine whether our data are robust, the sample (for each country) was separated into two halves, and factorial analysis was performed. As the analysis of the loadings did not differ substantially (per country, separately), we can affirm the validity of the results; i.e., they are robust and stable [56].

In addition, the Cronbach's [54] Alpha values are higher than 0.7 for both countries, with respect to the variables that represent the UG constructs i.e., motivators, indicating the reliability of the extracted factors. In sum, the model is acceptable for both samples, and we therefore proceed with factorial analysis. After factor extraction, an orthogonal Varimax rotation was performed on factors with engine values $\geq 1.0$, thus minimizing the number of variables with high loadings on a particular factor.

For both samples, four factors resulted from the analysis of the symptomatic variance, accounting for $72.25 \%$ of variance in the Netherlands and $60.07 \%$ of variance in Spain. The names established for these factors are similar to those used in UG theory [34,43]: F1-general integrative, F2-enjoyment or financial, F3 - network with community, and F4—product knowledge benefits.

For both countries, the factorial structure is consistent because all variables have a factor loading $>0.5$ for the factor that they allowed [55], as shown in Table 1.

Table 1. Factor loading EFA: the Netherlands (NL) versus Spain (SP).

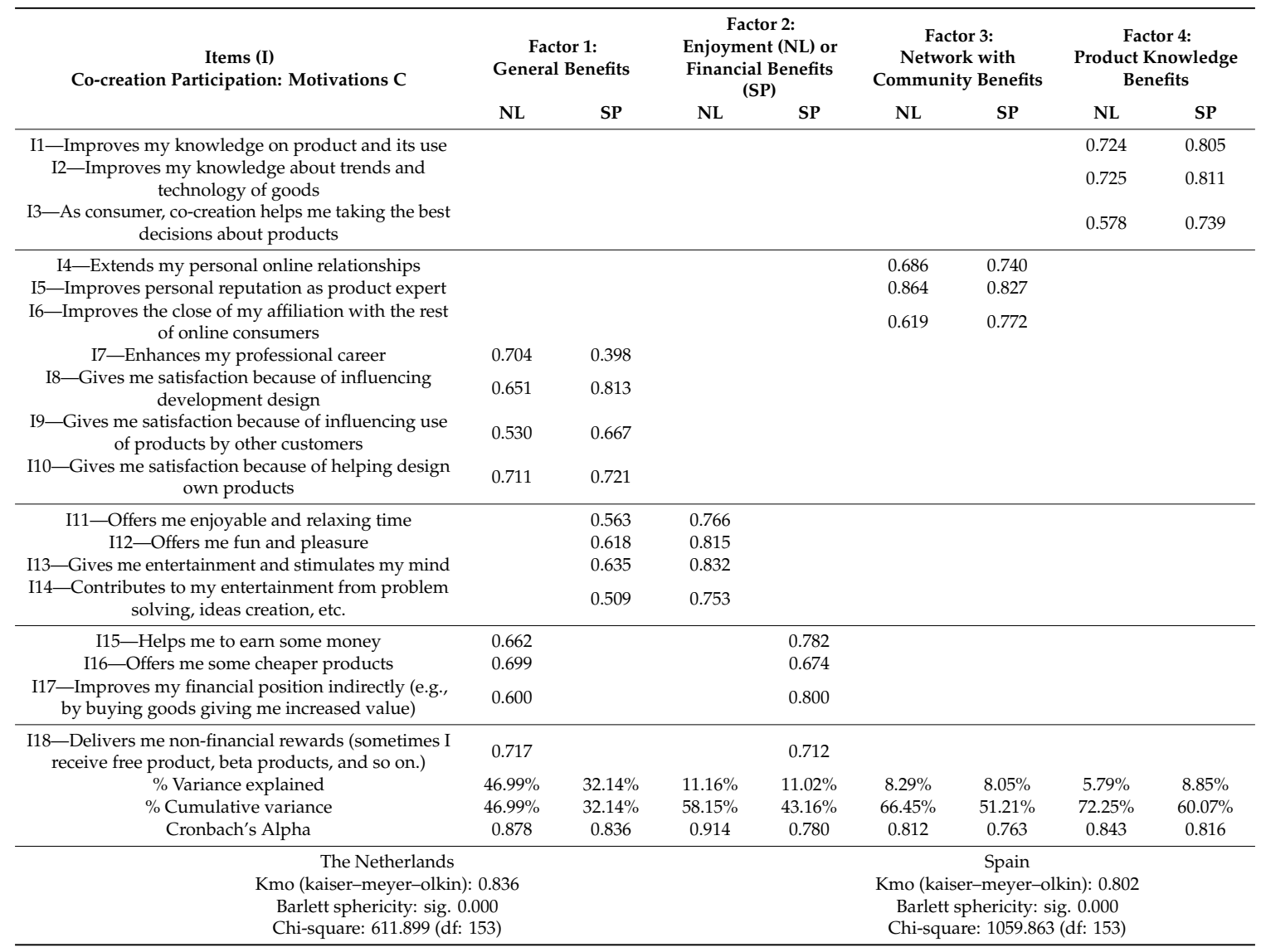


The main results of factorial analysis are shown in Table 1; the convergences between F3 (network with community benefits) and F4 (product knowledge benefits) are apparent. In both countries, the same items compose these factors. Nevertheless, in the case of F1 and F2, we can see some divergence. In the case of F1 (general benefits), the items for the Netherlands group are related to satisfaction and enrichment, while those for the Spain groups are related to satisfaction and enjoyment. On the other hand, F2 (enjoyment or financial benefits) is structured differently with respect to the two countries: The Netherlands includes hedonic variables (i.e., enjoyment benefits), and Spain includes enrichment variables (i.e., financial benefits).

\subsection{Latent Segmentation in Two European Countries: Profiles of Co-Creators Based on their Motives of Participing in Web Co-Creation Tasks}

The indicator variables were obtained by pondered average per each factor. It was calculated dividing the weight of each item with its standardized load by the sums of the full loadings of each factorial construct.

To define with more precision the resulting clusters, different descriptive variables or covariates that could have an influence on the motives of the sample were measured in order to refine the final obtained clusters, specifically, gender, age, nationality, and use of social networking sites (Table 2).

Table 2. Measured variables: indicators and covariates.

\begin{tabular}{cll}
\hline Var & \multicolumn{1}{c}{ Items Measured } & \multicolumn{1}{c}{ Categories } \\
\hline I & & \\
N & & \\
D & Motives of participation in co-creations: & Strongly disagree \\
I & F1-General Benefits & until \\
C & F2-Enjoyment (NL) or Financial Benefits (SP) & Strongly agree \\
A & F3-Network with Community Benefits & (5-Likert scale) \\
T & F4-Product Knowledge Benefits & \\
O & & \\
R & & \\
S & & Female \\
C & Gender & Male \\
O & & $<20$ years old \\
V & & $20-25$ \\
A & Age & $>25$ \\
R & & \\
I & Use of Social Media tools: & \\
A & LinkedIn & Have an account and use it normally \\
T & Blogger/Wordpress (blogs) & Have an account and use it rarely \\
E & YouTube/VIMEO (video) & Don't have any account but know it \\
S & Social bookmarking sites (e.g., Delicious) & Don't have any account and don't know \\
& Facebook & \\
& Twitter & \\
& Instagram (photo) & \\
\hline & &
\end{tabular}

As first step of latent segmentation, the optimum number of segments must be selected. The model is estimated from one (no heterogeneity presence) to eight (i.e., eight segments or heterogeneity presence). Table 3 shows the estimation process and the fit indexes per the eight models.

The model fit was evaluated according to the Bayesian Information Criterion (BIC), which makes it possible to identify the model with the least number of classes that best fits the data. The lowest BIC value was considered the best model indicator $[64,68]$. In this case, two co-creator groups represented the best alternative, as the BIC is minimized in this case. The statistic values included in Table 3 indicate that the model has a good fit (Es and R2 near 1). 
Table 3. Estimates and fix indexes: The Netherlands versus Spain.

\begin{tabular}{|c|c|c|c|c|c|c|c|c|c|c|c|c|}
\hline \multirow{2}{*}{$\begin{array}{c}\text { Number of } \\
\text { conglomerates }\end{array}$} & \multicolumn{2}{|c|}{ LL } & \multicolumn{2}{|c|}{ BIC(LL) } & \multicolumn{2}{|c|}{ Npar } & \multicolumn{2}{|c|}{ Class.Err. } & \multicolumn{2}{|c|}{$E_{s}$} & \multicolumn{2}{|c|}{$\mathbf{R}^{2}$} \\
\hline & NL & SP & NL & SP & NL & SP & NL & SP & NL & SP & NL & SP \\
\hline 1-Cluster & -216.2317 & -413.0483 & 733.6892 & 1315.267 & 77 & 102 & 0.0000 & 0.0000 & 1.0000 & 1.0000 & 1.0000 & 1.0000 \\
\hline 2-Cluster & -117.3402 & -322.2244 & 715.8593 & 1311.063 & 123 & 139 & 0.0000 & 0.0062 & 1.0000 & 0.9628 & 1.0000 & 0.9747 \\
\hline 3-Cluster & -98.8832 & -270.1752 & 858.8984 & 1384.409 & 169 & 176 & 0.0000 & 0.0021 & 1.0000 & 0.9895 & 1.0000 & 0.9933 \\
\hline 4-Cluster & -66.8999 & -220.2719 & 974.8847 & 1462.047 & 215 & 213 & 0.0001 & 0.0033 & 0.9996 & 0.9904 & 0.9998 & 0.9919 \\
\hline 5-Cluster & -37.1556 & -192.8670 & 1095.349 & 1584.681 & 261 & 250 & 0.0000 & 0.0006 & 0.9998 & 0.9977 & 0.9999 & 0.9984 \\
\hline 6-Cluster & -31.5015 & -155.6010 & 1263.994 & 1687.594 & 307 & 287 & 0.0000 & 0.0009 & 1.0000 & 0.9971 & 1.0000 & 0.9979 \\
\hline 7-Cluster & -10.9516 & -119.2523 & 1402.847 & 1792.340 & 353 & 324 & 0.0001 & 0.0003 & 0.9994 & 0.9988 & 0.9997 & 0.9993 \\
\hline 8-Cluster & -5.8578 & -79.5424 & 1572.612 & 1890.365 & 399 & 361 & 0.0000 & 0.0008 & 0.9998 & 0.9977 & 0.9999 & 0.9982 \\
\hline
\end{tabular}

The Wald statistic was analyzed to evaluate the statistical significance within a group of estimated parameters (Table 3). For all the indicators, a significant $p$-value associated with the Wald statistics was obtained, confirming that each indicator discriminates between the clusters in a significant way [64].

Table 4 also contains the profiles of the clusters obtained. In the upper part, the size and name assigned to the two groups is shown: The cluster named highly motivated co-creators includes $50 \%$ of Dutch co-innovators and $65.50 \%$ of Spanish co-innovators; the less motivated co-creator segment includes $50 \%$ of Dutch co-innovators and $34.50 \%$ of Spanish co-innovators.

Table 4. Profile of co-creators (indicators): motives for participating in co-creation activities in the Netherlands versus Spain.

\begin{tabular}{ccccccccc}
\hline & \multicolumn{2}{c}{ High Motivated } & \multicolumn{2}{c}{ Low Motivated } & \multicolumn{2}{c}{ Wald } & \multicolumn{2}{c}{ p-Value } \\
& NL & SP & NL & SP & NL & SP & NL & SP \\
\hline Cluster Size & $50.00 \%$ & $65.50 \%$ & $50.00 \%$ & $34.50 \%$ & & & & \\
Indicators & & & & & & & & \\
F1-General benefits & $\mathbf{2 . 6 6 7 6}$ & $\mathbf{3 . 8 2 0 8}$ & 2.4884 & 3.4243 & 14.5703 & 2.0103 & 0.00014 & 0.016 \\
F2-Enjoyment or financial benefits & $\mathbf{3 . 6 3 8 2}$ & $\mathbf{3 . 1 9 9 3}$ & 3.0410 & 3.0708 & 9.3799 & 3.9307 & 0.0022 & 0.0 .47 \\
F3-Network with community benefits & $\mathbf{2 . 7 9 5 9}$ & $\mathbf{3 . 1 5 9 3}$ & 2.2538 & 2.8373 & 4.1007 & 12.3201 & 0.043 & 0.00045 \\
F4-Product knowledge benefits & $\mathbf{3 . 8 0 2 9}$ & $\mathbf{3 . 9 4 7 5}$ & 2.5626 & 3.0209 & 19.3978 & 4.3644 & $1.1 \times 10^{-5}$ & 0.065 \\
\hline
\end{tabular}

In bold is marked the higher weight obtained by each factor per cluster.

As shown in Table 4, it is pertinent to note that in the Netherlands, both clusters have the same size (50\%). In contrast, in Spain, the first cluster (highly motivated co-creators) is higher than the second cluster (less motivated co-creators), whose sizes are $65.5 \%$ and $34.5 \%$. Thus, the number of Spanish co-creators is higher than the number of Dutch co-creators. We could test the assumption that higher level of social media activity is related also to motivation for co-creation due to, in this study, it is demonstrated that Spanish are more "fanatic" co-creators, maybe the time spend in social media activity plays a role in this (data corresponding with those indicated in section 3.1 from Statista [51]).

In both samples, all factors load into one cluster, which indicates highly motivated co-creators, as the mean values are higher for all factors (i.e., general benefits, enjoyment of financial benefits, network with community benefits, and product knowledge benefits). All values are higher than 2.5 (remember that the values range from 1-strongly disagree, to 5-strongly agree). Thus, all highly motivated co-creators consider participation in online co-creation activities in social media contexts important or very important. In fact, in Spain, the responses are more favorable towards online co-creation activities in social media environments; i.e., all factor values are higher than 3 points.

Other descriptive variables (i.e., personal characteristics and use of social network sites by co-creators) were included in segmentation model in order to complement the composition of the two segments based on, previously, only motivations. It is shown in Table 5. Independence tests associated with the Wald statistic conclude that significant differences exist between the segments ( $\geq 90 \%$ confidence level) regarding these descriptive variables (i.e., gender, age, and the use of different social media tools). 
Table 5. Profile of co-creators (covariates): descriptive criteria in the Netherlands vs Spain.

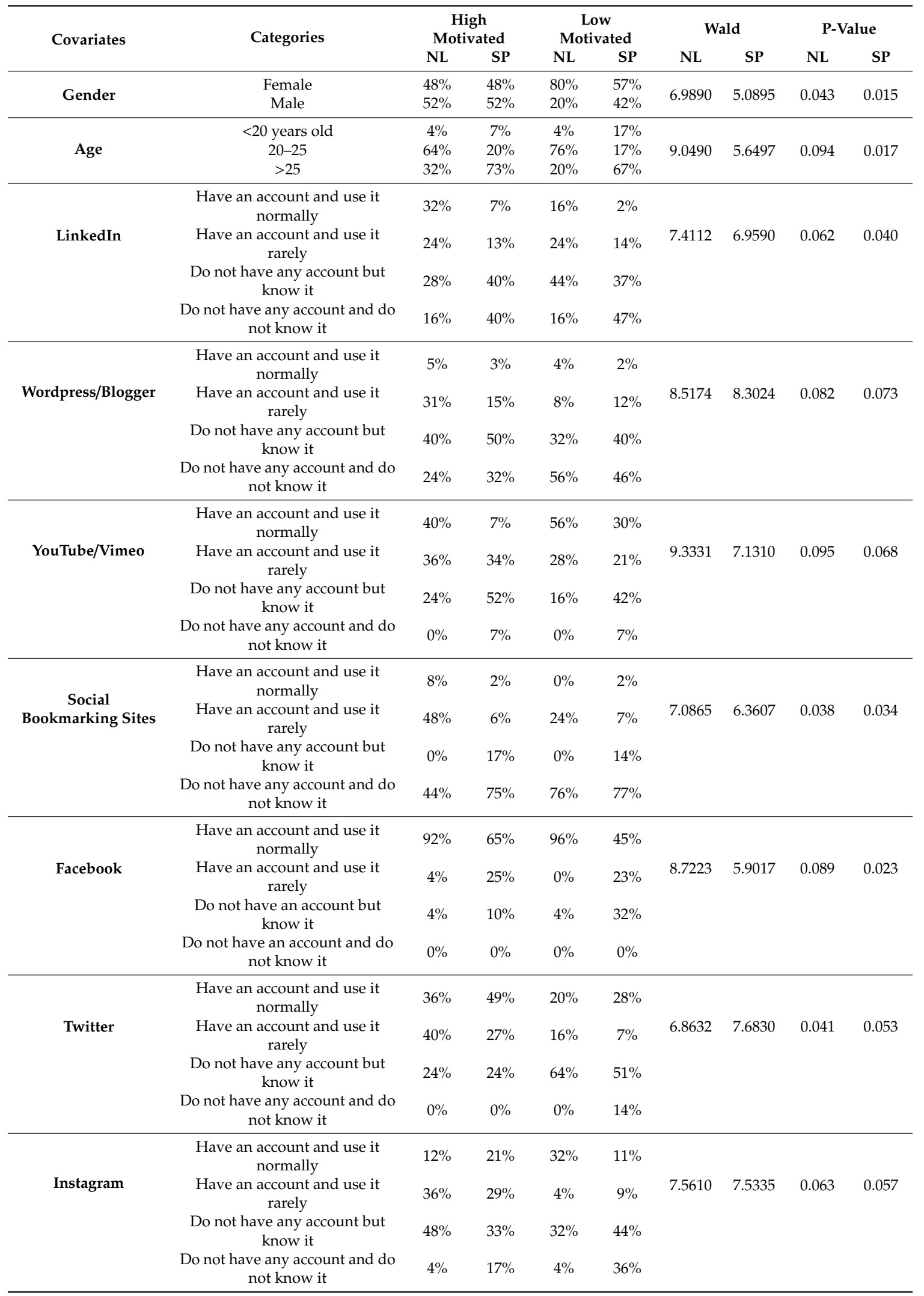

In sum, based on the data in Tables 4 and 5, we recognize two co-creator profiles, distinguishing between the Dutch and Spanish samples, as is indicated in next paragraphs. 
The highly motivated Dutch co-creator cluster presented a higher mean in F4-Product knowledge benefits (3.8020) and F2-Enjoyment benefits (3.6382). Moreover, this cluster showed a significant mean in F3-Network with community (2.7959) and F1-General benefits (2.6676). Compared with less motivated co-creators, this segment was mainly composed of males $(52 \%)$ who were more than 25 years old $(32 \%)$. With respect to the use of social media tools by this group in relation to the less motivated segment, it is important to note that highly motivated co-creators had an account on LinkedIn and used it regularly (32\%); most of the people in this group did not have an account with Wordpress and knew of it $(40 \%)$; a large percentage had an account on YouTube or Vimeo, Social Bookmarking Sites, and Facebook, and seldom used them (36\%, $48 \%$, and $4 \%$, respectively); some had an account and used it normally or rarely $(36 \%, 40 \%$, respectively); and others did not have an account on Instagram and knew of it (48\%).

The Spanish highly motivated co-creator cluster presented a higher mean in F4-Product knowledge benefits (3.9475) and F1-General benefits (3.8208). Moreover, this cluster showed a significant mean in F2-Financial benefits (3.1993) and F3-Network with community benefits (3.1593). Compared with less motivated co-creators, this segment was mainly composed of males (52\%) who were more than 25 years old (73\%). With respect to the use of social media tools by this group compared to the less motivated segment, it is important to note that few of these highly motivated co-creators had an account on LinkedIn and used it regularly $(7 \%)$, and the majority did not have an account but knew of this application (40\%); most people in this group do not have an account on Wordpress but knew of it (50\%); a high percentage had an account with YouTube or Vimeo and seldom used it $(34 \%)$ or did not have an account but knew it (52\%); they did have an account on Social Bookmarking sites and knew this (17\%); most people had an account on Facebook and Twitter and used it normally or rarely (65\% and 49\%, respectively); or they had an account on Instagram and seldom used it (29\%).

The less motivated Dutch and Spanish co-creators present a number of differences in their responses: The less motivated Dutch co-creator cluster presented a higher mean in F2-Enjoyment benefits (3.0410) and a low mean in F4-Product knowledge benefits (2.5626), F1-General benefits (2.4884), and F3-Network with community benefits (2.2538). Compared with highly motivated co-creators, the primary motivation of this segment was hedonic (remember that F2 in the case of the Dutch sample was only composed of enjoyment items) as opposed to product learning. This segment was composed mainly of females ( $80 \%$ ) between the ages of 20 and 25 years old (76\%). Of this group, $44 \%$ did not have an account on LinkedIn but knew it. They did not have an account on Wordpress and did not know it (56\%), but they had an account on YouTube/Vimeo and used it regularly (56\%). A large percentage of this group did not have an account on Social Bookmarking sites and did not know it (76\%). With respect to the other groups (i.e., highly motivated co-creators), this cluster had a higher percentage of people with an account on Facebook who used it normally (96\% versus $92 \%$ ). More than half of this group did not have an account on Twitter but knew it (64\%). This segment had an account on Instagram and used it regularly (32\% versus $12 \%)$.

The Spanish less motivated co-creator cluster presented a higher mean in F1-General benefits (3.4243), F2-Financial benefits (3.0708), and F4-Product knowledge benefits (3.0209) and a low mean in F3-Network with community benefits (2.8373). Unlike highly motivated co-creators, satisfaction and hedonic aspects were the main motivation for co-creating (i.e., general benefits) as opposed to product learning. This segment was composed mainly of females (57\%) less than 20 years old (17\%). Of this group, $47 \%$ did not have an account on LinkedIn and did not know it. Moreover, they did not have an account on Wordpress (56\%) or Blogger/Wordpress (46\%), and they did not know it; however, they had an account on YouTube/Vimeo and used it normally (30\%). A large percentage of this group did not have an account on Social Bookmarking sites and did not know it $(77 \%)$. With respect to the other group (i.e., highly motivated co-creators), this cluster had a larger percentage of people without an account on Facebook, Twitter, or Instagram but were aware of this (32\%, 51\%, 44\% versus 10\%, 24\%, $33 \%$ ). Of this group, $64 \%$ did not have an account on Twitter but knew it. Compared with the previous 
group, an important percentage of this segment did not have an account on Twitter (14\% versus $0 \%$ ) or Instagram (36\% versus $17 \%$ ) and was not aware of it.

As a consequence, five research questions (i.e., RQ1, RQ2, RQ3, RQ4, and RQ5) have been addressed in the previous paragraphs. In sum, four UG constructs are adequately significant to define the profile of users based on their motivation for online co-creation (RQ1-RQ4). Moreover, the analysis offers a segmentation of online co-creators based on UG theory and their personal and technology characteristics, distinguishing some convergences and differences between both countries (RQ5).

\section{Conclusions}

Co-Creation in innovation/new product development leads to a better fit between customer needs and products and to improved relationships between buyers and suppliers; online co-creation has an additional advantage in that producers are able to recruit co-creating customers on a global scale and improve their innovation processes and output. Cooperation between users and producers on innovation projects results in competitive advantages because suppliers are better able to comply with customer demands for value; producers gain insight into the demands, ideas, and buying process of customers. Successfully recruiting the most promising customers as online co-creators depends on the ability to understand customer motives in addition to the right communication approaches. In globalized settings, such efforts are challenging because cultural differences have an impact on motivation.

The analysis identifies two segments of co-creators, each with different profiles and motivations for online collaboration in new product development: Highly Motivated and Less Motivated co-creators.

Highly Motivated Co-creators: The empirical results indicate that the main motive of the highly motivated segment in both countries is to improve their product knowledge (i.e., F4-product knowledge benefits), followed by hedonic motives in both populations. A comparison of the relative size of the Highly Motivated segments in the two countries indicates that the Spanish participants show a higher level of motivation than their Dutch counterparts. This might be attributed to the fact that while the adoption of Internet technologies among the Spanish is lower than it is among the Dutch, the adoption rate of social media tools in general, and Social Networking Sites in particular, is higher in Spain. Spanish people also spend more time on Social Networking Sites [51], which might be because the Spanish are generally more extroverted [52]. The high level of individualism in the Netherlands as opposed to Spain [52] indicates that this society has more individual and individualist attitudes and fewer ties with other people.

While the two most important motives among both populations are similar, there is a difference in the third and fourth motives for online co-creation. For the Spanish, the third most important motive for online co-creation is to obtain enrichment; the Dutch, however, are attracted by the networking possibilities associated with online co-creation. Cultural characteristics could play a role in these differences, but age is also an issue: The Dutch sample is younger than the Spanish sample. The age difference as well as social media preferences can explain this difference: Social media applications like LinkedIn, YouTube, and Facebook are used by highly motivated Dutch co-creators, more than they are by Spanish co-creators. In contrast, highly motivated Spanish co-creators use Twitter and Instagram more than Dutch co-creators do; the Dutch are more self-sufficient (individualists) and therefore use social networking sites such as LinkedIn rather than hedonic and communicative sites such as Instagram and Twitter, which are preferred by Spaniards.

Less Motivated Co-creators: The less motivated co-creators segment in both countries co-innovate for the same reason: Hedonism. A secondary motive for the Spanish segment is enrichment, whereas the Dutch are motivated by product knowledge. As in the highly motivated segment, the Spanish participants in the less motivated segment also show a higher level of motivation for online co-creation activities than the same segment of Dutch participants. The percentage of less motivated female co-creators is higher in the Netherlands possibly because of the higher level of masculinity in Spain. Spanish people have a tendency to be more competitive and strive for success. The second and 
third motives in both groups in this segment are satisfaction and enrichment. The practical value of distinguishing between two types of motivated co-creators is that the approach used by marketers to attract co-creators can be modified according to the needs of the project. Marketers can target the appropriate co-creators using the right communication format: If less motivated consumers are targeted, hedonic elements must underpin the recruitment campaign; highly motivated customers are attracted by rationales that appeal to their need for knowledge or self-actualization. These strategies might be used by marketers to arrange competitions through service [9] within this new open collaboration context.

The average age of both samples is also different in the less motivated cluster. The Dutch sample is younger than the Spanish sample. With respect to the use of social media tools, an interesting difference is the regular use of LinkedIn, YouTube, Facebook, and Instagram by less motivated Dutch co-creators as opposed to the use of Twitter by less motivated Spanish co-creators. In this respect, our findings are similar to Nambisan and Baron [34] and Füller et al. [8], who study the triggers for participation in virtual innovation environments. The findings of Nambisan and Baron [34] support the thesis that the four kinds of benefits-from the UG theory- have a significant and positive influence on user participation in product support within online contexts. Füller et al. [8] also conclude that a product-related motive (knowledge) is an important motivator for co-creating customers, while financial motives are not important.

The positive impact of benefits related to social and hedonic motivations on the likelihood of users participating in co-creation activities, also are consistent with the results obtained by Wang and Fesenmaier [69], who study customer activities in interactive online travelling communities.

Furthermore, indicate that recognition from the network community motivates individuals to contribute to co-creation processes, which can be counted among the benefits related to social integration [70] and social innovation in different sectors such as public administrations [71,72], health sites [73], and so on.

As main limitation our our research, it is recognize the necessity of conducting a sample selection bias test [74]. Finally, as future research, it would be interesting to develop a structural equation model linking the personal characteristics indicated in this model together with another ones (e.g., unwillingness to communicate, satisfaction, affinity with the Internet, social presence, etc.) [75] with motivations analyzed in UG theory.

Author Contributions: Conceptualization, Validation, Writing-review \& editing, E.C. and C.L.-R.; Data curation, Formal analysis, Investigation, Methodology, Supervision, C.L.-R.; Resources (field work), Netquest ${ }^{\circledR}$; Visualization, Writing-original draft, E.C.; English writing-review \& editing, American Journal Experts ${ }^{\circledR}$ (www.aje.com).

Funding: This study has been developed within the Research Project funded by Fundación Ramón Areces, entitled "La colaboración abierta en Internet como estrategia de innovación e internacionalización del sector de moda y complementos [open collaboration in the Internet as innovation and internationalization strategies by fashion sector]" (2015-2018).

Conflicts of Interest: The authors declare no conflict of interest.

\section{References}

1. Fitzsimmons, J.A. Consumer participation and productivity in service operations. Interfaces 1985, 15, 60-67. [CrossRef]

2. Prahalad, C.K.; Ramaswamy, V. The Future of Competition: Co-Creating Unique Value with Customers; Harvard Business Review Press: Boston, MA, USA, 2004.

3. Ramaswamy, V. Co-creating experiences with customers: New paradigm of value creation. TATA J. Manag. 2005, 8, 6-14.

4. Von Hippel, E. Democratizing innovation: The evolving phenomenon of user innovation. J. Betriebswirtschaft 2005, 55, 63-78. [CrossRef]

5. Gemser, G.; Perks, H. Co-creation with customers: An evolving innovation research field. J. Prod. Innov. Manag. 2015, 32, 660-665. [CrossRef] 
6. Van Blokland, W.B.; Santema, S.C. Value Chain Innovation Processes and the Influence of Co-Innovation. In Proceedings of the 22nd IMP Conference, Ljubljana, Slovenia, 9-10 October 2006.

7. Malone, T.W.; Laubacher, R.; Dellarocas, C. The collective intelligence genome. MIT Sloan Manag. Rev. 2010, 51, 5-18. [CrossRef]

8. Füller, J.; Faullant, R.; Matzler, K. Triggers for virtual customer integration in the development of medical equipment-From a manufacturer and a user's perspective. Ind. Mark. Manag. 2010, 39, 1376-1383. [CrossRef]

9. Lusch, R.F.; Vargo, S.L.; O’Brien, M. Competing through service: Insights from service-dominant logic. J. Retail. 2007, 83, 5-18. [CrossRef]

10. Constantinides, E.; Romero, C.L.; Boria, M.A.G. Social media: A new frontier for retailers? In European Retail Research; Swoboda, B., Morschett, D., Rudolph, T., Schnedlitz, P., Schramm-Klein, H., Eds.; Gabler Verlag: Wiesbaden, Germany, 2008; pp. 1-28.

11. Peng, X.; Babar, M.A.; Ebert, C. Collaborative software development platforms for crowdsourcing. IEEE Softw. 2014, 31, 30-36. [CrossRef]

12. Hoornaert, S.; Ballings, M.; Malthouse, E.C.; Van den Poel, D. Identifying new product ideas: Waiting for the wisdom of the crowd or screening ideas in real time. J. Prod. Innov. Manag. 2017, 34, 580-597. [CrossRef]

13. Zwartjes, B.C. Co-Creation from a Consumer Perspective: Consumer Motivations to Partake in and Success Factors of a Co-Creation Initiative. Master's Thesis, Wageningen University, Wageningen, The Netherlands, 2011.

14. McKinsey Global Institute. The Social Economy: Unlocking Value and Productivity through Social Technologies; McKinsey Global Institute: New York, NY, USA, 2011.

15. Djelassi, S.; Decoopman, I. Customers' participation in product development through crowdsourcing: Issues and implications. Ind. Mark. Manag. 2013, 42, 683-692. [CrossRef]

16. Ostrom, A.L.; Parasuraman, A.; Bowen, D.E.; Patrício, L.; Voss, C.A. Service research priorities in a rapidly changing context. J. Serv. Res. 2015, 18, 127-159. [CrossRef]

17. Leclercq, T.; Hammedi, W.; Poncin, I. The boundaries of gamification for engaging customers: Effects of losing a contest in online co-creation communities. J. Interact. Mark. 2018, 44, 82-101. [CrossRef]

18. Fielding, R.T. Shared leadership in the apache project. Commun. ACM 1999, 42, 42-43. [CrossRef]

19. Halloran, T.J.; Scherlis, W.L. High quality and open source software practices. In Meeting Challenges and Surviving Success: 2nd Workshop on Open Source Software Engineering; ACM: Orlando, FL, USA, 2002; pp. 669-670.

20. Nakakoji, K.; Yamamoto, Y.; Nishinaka, Y.; Kishida, K.; Ye, Y. Evolution patterns of open-source software systems and communities. In IWPSE 2002: Proceedings of the International Workshop on Principles of Software Evolution; ACM: New York, NY, USA, 2002; pp. 76-85.

21. Rohrbeck, R.; Hölzle, K.; Gemünden, H.G. Opening up for competitive advantage-How deutsche telekom creates an open innovation ecosystem. R D Manag. 2009, 39, 420-430. [CrossRef]

22. Storbacka, K.; Brodie, R.J.; Böhmann, T.; Maglio, P.P.; Nenonen, S. Actor engagement as a microfoundation for value co-creation. J. Bus. Res. 2016, 69, 3008-3017. [CrossRef]

23. Ranjan, K.R.; Read, S. Value co-creation: Concept and measurement. J. Acad. Mark. Sci. 2016, 44, $290-315$. [CrossRef]

24. Füller, J. Refining virtual co-creation from a consumer perspective. Calif. Manag. Rev. 2010, 52, 98-122. [CrossRef]

25. Bharti, K.; Agrawal, R.; Sharma, V. What drives the customer of world's largest market to participate in value co-creation? Mark. Intell. Plan. 2014, 32, 413-435. [CrossRef]

26. Hofstede, G. Culture's Consequences: International Differences in Work-Related Values; SAGE Publications: Beverly Hills, CA, USA, 1980.

27. Hofstede, G. Culture's Consequences: Comparing Values, Behaviors, Institutions and Organizations across Nations; SAGE Publications: Thousand Oaks, CA, USA, 2001.

28. Eurostat. Digital Economy and Society Statistics-Households and Individuals. Available online: https://ec.europa.eu/eurostat/statistics-explained/index.php/Digital_economy_and_society_statistics_-_ households_and_individuals (accessed on 5 May 2019).

29. Kleemann, F.; Voß, G.G.; Rieder, K. Crowdsourcing und der arbeitende konsument. Arb. Ind. Stud. 2008, 1, $29-44$.

30. Chesbrough, H.W. Open Innovation: The New Imperative for Creating and Profiting from Technology; Harvard Business School Press: Boston, MA, USA, 2003. 
31. Whelan, E.; Teigland, R.; Donnellan, B.; Golden, W. How internet technologies impact information flows in R\&D: Reconsidering the technological gatekeeper. $R$ D Manag. 2010, 40, 400-413. [CrossRef]

32. Chang, R.Y.; Peng, S.-L.; Lee, G.; Chang, C.J. Comparing group characteristics to explain community structures in social media networks. J. Internet Technol. 2015, 16, 957-962. [CrossRef]

33. Hoyer, W.D.; Chandy, R.; Dorotic, M.; Krafft, M.; Singh, S.S. Consumer cocreation in new product development. J. Serv. Res. 2010, 13, 283-296. [CrossRef]

34. Nambisan, S.; Baron, R.A. Virtual customer environments: Testing a model of voluntary participation in value co-creation activities. J. Prod. Innov. Manag. 2009, 26, 388-406. [CrossRef]

35. Xia, L.; Suri, R. Trading effort for money: Consumers' cocreation motivation and the pricing of service options. J. Serv. Res. 2014, 17, 229-242. [CrossRef]

36. Franke, N.; Shah, S. How communities support innovative activities: An exploration of assistance and sharing among end-users. Res. Policy 2003, 32, 157-178. [CrossRef]

37. Katz, E.; Blumler, J.G.; Gurevitch, M. Utilization of mass communication by the individual. In The Uses of Mass Communications: Current Perspectives on Gratifications Research; Blumler, J.G., Katz, E., Eds.; Sage Publications: Beverly Hills, CA, USA, 1974; pp. 19-32.

38. Urista, M.A.; Dong, Q.; Day, K.D. Explaining why young adults use myspace and facebook through uses and gratifications theory. Hum. Commun. 2008, 12, 215-229.

39. Eighmey, J.; McCord, L. Adding value in the information age: Uses and gratifications of the world-wide web. In Conference on Telecommunications and Information, Markets; University of Rhode Island: Newport, RI, USA, 1995.

40. Newhagen, J.E.; Rafaeli, S. Why communication researchers should study the internet: A dialogue. J. Commun. 1996, 46, 4-13. [CrossRef]

41. Ruggiero, T.E. Uses and gratifications theory in the 21st century. Mass Commun. Soc. 2000, 3, 3-37. [CrossRef]

42. Leung, L.; Wei, R. More than just talk on the move: Uses and gratifications of the cellular phone. J. Mass Commun. Q. 2000, 77, 308-320. [CrossRef]

43. Luo, X. Uses and gratifications theory and e-consumer behaviors. J. Interact. Advert. 2002, 2, 34-41. [CrossRef]

44. Zolkepli, I.A.; Kamarulzaman, Y. Social media adoption: The role of media needs and innovation characteristics. Comput. Hum. Behav. 2015, 43, 189-209. [CrossRef]

45. Nambisan, S.; Baron, R.A. Interactions in virtual customer environments: Implications for product support and customer relationship management. J. Interact. Mark. 2007, 21, 42-62. [CrossRef]

46. Blasco, L.; Jimenez, J.; Hernández, B. Los procesos de Co-Creación y el Engagement del Cliente: Un Análisis Empírico en Medios Interactivos [The Co-Creation Processes and the Engagement of Customer: An Empirical Analysis in Interactive Media]. Ph.D. Thesis, University of Zaragoza, Zaragoza, Spain, 2014.

47. Kristensson, P.; Johansson, N.; Matthing, J. Key strategies for the successful involvement of customers in the co-creation of new technology-based services. Int. J. Serv. Ind. Manag. 2008, 19, 474-491. [CrossRef]

48. Vargo, S.L.; Maglio, P.P.; Akaka, M.A. On value and value co-creation: A service systems and service logic perspective. Eur. Manag. J. 2008, 26, 145-152. [CrossRef]

49. Grande, I. Marketing Crosscultural; Esic Editorial: Madrid, Spain, 2004.

50. Statista. Active Social Media Penetration in European Countries in January 2018. Available online: https://www.statista.com/statistics/295660/active-social-media-penetration-in-european-countries/ (accessed on 16 April 2019).

51. Statista. Average Daily Social Media Use Via any Device in Selected European Countries in 2017. Available online: https://www.statista.com/statistics/719966/average-daily-social-media-use-in-selected-europeancountries/ (accessed on 7 January 2019).

52. Hofstede, G. The Hofstede Centre. Available online: http://geert-hofstede.com (accessed on 6 February 2018).

53. Bowden, A.; Fox-Rushby, J.A.; Nyandieka, L.; Wanjau, J. Methods for pre-testing and piloting survey questions: Illustrations from the KENQOL survey of health-related quality of life. Health Policy Plan. 2002, 17, 322-330. [CrossRef]

54. Cronbach, L.J. Coefficient alpha and the internal structure of tests. Psychometrika 1951, 16, 297-334. [CrossRef]

55. Hair, J.; Anderson, R.; Tatham, R.; Black, W. Multivariate Data Analysis; Prentice-Hall: London, UK, 1998.

56. Hair, J.; Anderson, R.E.; Tatham, R.L.; Black, W.C. Multivariate Data Analysis with Readings; Prentice-Hall: Englewood Cliffs, NJ, USA, 1995. 
57. McLure Wasko, M.; Faraj, S. "It is what one does": Why people participate and help others in electronic communities of practice. J. Strateg. Inf. Syst. 2000, 9, 155-173. [CrossRef]

58. Hertel, G.; Niedner, S.; Herrmann, S. Motivation of software developers in open source projects: An internet-based survey of contributors to the linux kernel. Res. Policy 2003, 32, 1159-1177. [CrossRef]

59. Kollock, P. The economies of on-line cooperation: Gifts, and public goods in cyberspace. In Communities in Cyberspace; Smith, M.A., Kollock, P., Eds.; Routledge: London, UK, 1999; pp. 220-239.

60. De Rada, I.V.D. Diseño de tipologías de consumidores mediante la utilización conjunta del análisis cluster y otras técnicas multivariantes [Design of consumers' typologies through the join use of cluster analysis and other multivariate techniques]. Rev. Esp. Econ. Agrar. 1998, 182, 75-104.

61. Frías-Navarro, D.; Soler, M.P. Prácticas del análisis factorial exploratorio (AFE) en la investigación sobre conducta del consumidor en marketing [Exploratory factorial analysis practices in the research on consumer behaviour in marketing]. Suma Psicol. 2012, 19, 47-58.

62. Dillon, W.R.; Kumar, A. Latent structure and other mixture models in marketing: An integrative survey and overview. In Advanced Methods of Marketing Research; Bagozzi, R.P., Ed.; Blackwell Publishing House Business: Cambridge, MA, USA, 1994; pp. 190-222.

63. McLachlan, G.J.; Basford, K.E. Mixture Models: Inference and Applications to Clustering; Marcel Dekker: New York, NY, USA, 1988.

64. Vermunt, J.K.; Magidson, J. Latent Gold 4.0 User's Guide; Statistical Innovation, Inc.: Belmont, MA, USA, 2005.

65. Guttman, L. Mathematical Thinking in the Social Sciences; Free Press: New York, NY, USA, 1954.

66. Bartlett, M.S. A note on the multiplying factors for various approximations. J. R. Stat. Soc. Series B 1954, 16, 296-298. [CrossRef]

67. Kaiser, H.F. A second generation little jiffy. Psychometrika 1970, 35, 401-415. [CrossRef]

68. Vermunt, J.K.; Magidson, J. Latent class cluster analysis. In Applied Latent Class Analysis; Hagenaars, J.A., McCutcheon, A.L., Eds.; Cambridge University Press: Cambridge, UK, 2002; pp. 89-106.

69. Wang, Y.; Fesenmaier, D.R. Towards understanding members' general participation in and active contribution to an online travel community. Tour. Manag. 2004, 25, 709-722. [CrossRef]

70. Jeppesen, L.B.; Frederiksen, L. Why do users contribute to firm-hosted user communities? The case of computer-controlled music instruments. Organ. Sci. 2006, 17, 45-63. [CrossRef]

71. Chin, T.; Yang, Y.; Zhang, P.; Yu, X.; Cao, L. Co-creation of Social Innovation: Corporate Universities as Innovative Strategies for Chinese Firms to Engage with Society. Sustainability 2019, 11, 1438. [CrossRef]

72. Perello-Marín, M.R.; Gabriela Ribes-Giner, G.; Pantoja Díaz, O. Enhancing Education for Sustainable Development in Environmental University Programmes: A Co-Creation Approach. Sustainability 2018, 10, 158. [CrossRef]

73. Russo, G.; Moretta Tartaglione, A.; Cavacece, Y. Empowering Patients to Co-Create a Sustainable Healthcare Value. Sustainability 2019, 11, 1315. [CrossRef]

74. Ruiz Espejo, M. Objective unbiased estimation for nonresponse. Estadística Española 2015, 57, $29-37$.

75. Papacharissi, Z.; Rubien, A.M. Predictors of Internet Use. J. Broadcast. Electron. Media 2000, 44, 175-196. [CrossRef]

(C) 2019 by the authors. Licensee MDPI, Basel, Switzerland. This article is an open access article distributed under the terms and conditions of the Creative Commons Attribution (CC BY) license (http://creativecommons.org/licenses/by/4.0/). 